\title{
A note on tax research
}

\author{
Martin Jacob \\ WHU - Otto Beisheim School of Management, Vallendar, Germany \\ Email: martin.jacob@whu.edu
}

\section{INTRODUCTION}

"Business goes global, taxes stay local." This sentence typically describes key tax issues in the business practice, research, and policymaking. While each country has its own set of tax rules, businesses operate not only within one country, but also across countries. On the one hand, this increases compliance costs, as firms have to comply with various sets of tax rules. On the other hand, different tax rules give firms the opportunity to avoid taxes by shifting profits to low-tax jurisdictions. For decades, tax avoidance has particularly attracted the interest of scholars, policymakers, and the public opinion. At the same time, policymakers are concerned about the actual consequences that taxes have on business decisions, such as investment and corporate payout.

This editorial aims to summarize the recent tax literature and state the reasons why there is a need for further research, from different perspectives and various countries, addressing the consequences of taxes on firms and their shareholders. In fact, there are many things scholars, policymakers, and practitioners can learn through the experience and settings of various countries, as tax research in accounting and finance may substantially contribute to our understanding of firm behavior and how the institutional characteristics of a country shape the effect of taxes on firm behavior.

Herein, I focus on two main topics. The first topic relates to the actual effects of taxes on firm behavior, such as investment and corporate payout. Policymakers around the world frequently change corporate taxes or payout taxes to spur economic growth (e.g. Djankov, Ganser, McLiesh, Ramalho \& Shleifer, 2010; Becker, Jacob \& Jacob, 2013; Yagan, 2015; Alstadsæter, Jacob \& Michaely, 2017; Jacob, Müller \& Michaely, 2017; Giroud \& Rauh, 2017; Patel, Seegert \& Smith, 2017). Empirical tax research may inform policymakers whether the intended goals are met.

The second topic refers to corporate tax avoidance and profit shifting. Over the past decades, many countries have increased their pressure on corporations. Despite these efforts, it seems as if there is increased tax avoidance, at least among U.S. firms (Klassen \& Laplante, 2012; Dyreng, Hanlon, Maydew \& Thornock, 2017). Thus, in sections 2 and 3, I summarize some of the main findings of empirical literature on the actual effects of taxes and tax avoidance, respectively. This editorial is not a review of the tax literature. I took the liberty to focus on two topics, leaving aside other significant topics, such as informativeness of the tax information in financial statements or book-tax differences.

For both topics, I discuss how research conducted in other countries, such as Brazil, can contribute to our understanding of firm behavior (section 4). Considering that the Brazilian tax system may be regarded as more complex than the other countries' set of tax rules and having in mind that its local organization differ from many countries, Brazil provides researchers with settings that can yield interesting insights to accounting and finance scholars. 


\section{REAL EFFECTS OF TAXATION}

For several decades, the public economics, finance, and accounting literature has examined the effect of taxation on corporate policies, such as investment and corporate payout to shareholders. Understanding these effects is key to a policy debate, as taxes are often altered to foster growth and investment. Many studies available in the literature have examined these effects. For instance, Djankov et al. (2010) resort to a cross-section of 85 countries and examine how corporate taxes and other taxes are related to aggregate investment. More recently, Giroud and Rauh (2017), as well as Patel et al. (2017), examine the effect of corporate taxes on investment using administrative tax data from the United States of America (USA) collectively; these papers (as many others) show that corporate taxes adversely affect corporate investment. Also, the literature documents that corporate payout taxation - dividends and stock repurchases - affect the allocation of investment across financially constrained and unconstrained firms (e.g. Becker et al., 2013; Alstadsæter et al., 2017), while leaving aggregate investments unaffected (cf. Yagan, 2015). Finally, Jacob et al. (2017) show that consumption taxes can have substantial effects on corporate investments, as firms are unable to fully pass on the burden of these taxes to their customers. The main focus of all of these papers lies on establishing a causal effect of taxes on corporate investment. A natural next step might be examining whether such effects are observed in developing countries with different institutional details, as well as different levels of tax compliance and complexity.

Another major strand of the accounting and finance literature on tax examines how dividend and capital gain taxation affects corporate payout. As for the investment literature, there is plenty of evidence from single-country studies (e.g. Chetty \& Saez, 2005 and Blouin, Raedy \& Shackelford, 2011 for the USA; Rau \& Vermaelen, 2002 and Oswald \& Young, 2004 for the United Kingdom (UK); and Lee, Liu, Roll \& Subrahmanyam, 2006 for Taiwan), as well as from international panel data (Jacob \& Jacob, 2013). Although there seems to be a common understanding that taxes affect dividend payout, the magnitude of the tax response differs heavily across studies, leading some scholars to conclude that dividend taxes have no or a second-order effect on the payout policy (Julio \& Ikenberry, 2004; Brav, Graham, Harvey \& Michaely, 2008). There are some explanations for the lack of a response. For instance, agency issues (Chetty \& Saez, 2005) or shareholder conflicts (Jacob \& Michaely, 2017) can mute the impact of dividend taxes on corporate payout. However, the role of country-level institutions, tax complexity, tax compliance, or agency importance, as well as shareholder conflicts in developing countries due to tax sensitivity of payout, has not been fully understood, thus this constitutes a potential path for further research using data from developing countries.

\section{CORPORATE TAX AVOIDANCE AND PROFIT SHIFTING}

Another major strand of the literature relates to studies examining the determinants and consequences of tax avoidance (cf. Wilde \& Wilson, in press). While most of the literature focuses on U.S. firms (cf. Dyreng et al., 2017; Dyreng, Jacob, Jiang \& Müller, 2018), more recently, several papers have emerged by using international data. These papers highlight differences in tax avoidance across countries, e.g. due to the way foreign earnings are taxed (Markle, 2016), due to the existence of imputation tax credits for dividend payout (e.g. Amiram, Bauer \& Frank, 2017; McClure, Lanis, Wells \& Govendir, 2018) or due to the book-tax conformity level (Atwood, Drake, Myers \& Meyers, 2012).

However, little is known about tax avoidance in developing countries and how institutional characteristics shape the incentives to avoid taxes. Dyreng et al. (2018) introduce and test a tax avoidance model in which firms can pass on taxes to stakeholders. A core element of Dyreng et al. (2018) is deriving an expression for the cost-benefit trade-off firms face when deciding on the profit-maximizing level of tax avoidance. This model can serve as a starting point to examine tax avoidance in a developing country or in a setting with tax complexity. Predicting how a tax complexity such as the Brazilian one affects tax avoidance is not clear ex ante. On the one hand, a highly complex tax system may create loopholes exploited by firms. On the other hand, a highly complex tax system may increase the likelihood of accidental and unintentional mistakes in tax compliance that can lead to back taxes and tax audits. Hence, it is an empirical issue if tax complexity hinders or facilitates tax avoidance. 


\section{FINAL REMARKS AND OUTLOOK}

Brazil has one of the highest corporate tax rates in the world and it has a value added tax (VAT) above most of the other countries (cf. Jacob et al., 2017). Also, Brazil is regarded as one of the most complex tax jurisdictions in the world. Considering this complexity, tax research in Brazil or studies using data from Brazil can yield very interesting insights that scholars are not able to gain readily in other jurisdictions. Recently, there have emerged several studies on the effect of tax enforcement and corporate tax audits on firm behavior. For instance, stricter tax enforcement can reduce tax avoidance (Hoopes, Mescall \& Pittman, 2012) and improve financial reporting quality (Hanlon, Hoopes \& Shroff, 2014). Ultimately, tax enforcement can reduce stock price crash risk (Bauer, Fang \& Pittman, 2017) and improve the lending from banks for corporate borrowers (Gallemore \& Jacob, 2018). However, this evidence comes mostly from the USA. How tax enforcement and corporate tax audit efforts affect firm behavior in developing countries is less commonly known. Given the ongoing debate about tax compliance (cf. International Monetary Fund, 2015) and tax complexity (International Monetary Fund \& Organisation for Economic Co-Operation and Development, 2017), analyzing Brazilian firms in this complex environment may constitute an interesting path for research.

The same holds for research on the actual effects of taxation and corporate tax avoidance. Understanding how tax complexity and tax enforcement in developing countries affect, for instance, investment-tax sensitivity is important for policymakers. Likewise, understanding the determinants and consequences of tax avoidance in a developing country with such a tax complexity level is significant for the allocation of scarce tax enforcement resources (cf. International Monetary Fund, 2015). Taken together, more intense tax research by accounting and finance scholars can contribute to policy debates, as well as to the general understanding of firm behavior. Accounting and finance scholars may exploit their institutional knowledge to provide academics and policymakers with relevant research-based answers.

\section{REFERENCES}

Alstadsæter, A., Jacob, M., \& Michaely, R. (2017). Do dividend taxes affect corporate investment? Journal of Public Economics, 151, 74-83.

Amiram, D., Bauer, A. M., \& Frank, M. M. (2017). Tax avoidance at public corporations driven by shareholder taxes: evidence from changes in dividend tax policy (Working Paper No. 2111467). Charlottesville, VA: Darden Business School.

Atwood, T. J., Drake, M. S., Myers, J. N., and Meyers, L. A. (2012). Home country tax system characteristics and corporate tax avoidance: international evidence. The Accounting Review, 87, 1831-1860.

Bauer, A. M., Fang, X., \& Pittman, J. (2017). Does stock price crash risk subside when the IRS imposes stricter corporate tax enforcement? (Working Paper). [s.l]: University of Illinois/Georgia State University/Memorial University of Newfoundland.

Becker, B., Jacob, M., \& Jacob, M. (2013). Payout taxes and the allocation of investment. Journal of Financial Economics, 107, $1-24$.

Blouin, J. L., Raedy, J. S., \& Shackelford, D. A. (2011). Dividends, share repurchases, and tax clienteles: evidence from the 2003 reductions in shareholder taxes. The Accounting Review, 86, 887-914.

Brav, A., Graham, J. R., Harvey, C. R., \& Michaely, R. (2008). The effect of the May 2003 dividend tax cut on corporate dividend policy: empirical and survey evidence. National Tax Journal, 61, 381-396.

Chetty, R., \& Saez, E. (2005). Dividend taxes and corporate behavior: evidence from the 2003 dividend tax cut. Quarterly Journal of Economics, 120, 791-833.

Djankov, S., Ganser, T., McLiesh, C., Ramalho, R., \& Shleifer, A. (2010). The effect of corporate taxes on investment and entrepreneurship. American Economic Journal: Macroeconomics, 2, 31-64.

Dyreng, S. D., Hanlon, M., \& Maydew E. L. (2008). Long-run corporate tax avoidance. The Accounting Review, 83, 61-82.

Dyreng, S. D., Hanlon, M., Maydew, E. L., \& Thornock, J. R. (2017). Changes in corporate effective tax rates over the past twenty-five years. Journal of Financial Economics, 124, 441463.

Dyreng, S. D., Jacob, M., Jiang, X., \& Müller, M. A. (2018). Tax incidence and tax avoidance (SSRN Working Paper). [s.l]: [s.n].

Gallemore, J., \& Jacob, M. (2018). Tax enforcement externalities and the banking sector (Working Paper). [s.l]: University of Chicago/WHU - Otto Beisheim School of Management.

Giroud, X., \& Rauh, J. (2017). State taxation and the reallocation of business activity: evidence from establishment-level data (Working Paper). [s.l]: [s.n]. 
Hanlon, M., Hoopes, J. L., \& Shroff, N. (2014). The effect of tax authority monitoring and enforcement on financial reporting quality. Journal of the American Taxation Association, 36, 137-170.

Hoopes, J. L., Mescall, D., \& Pittman, J. A. (2012). Do IRS audits deter corporate tax avoidance? The Accounting Review, 87, 1603-1639.

International Monetary Fund. (2015). Current challenges in revenue mobilization: improving tax compliance. Retrieved from https://www.imf.org/external/np/pp/ eng/2015/020215a.pdf

International Monetary Fund \& Organisation for Economic CoOperation and Development. (2017, March). Report for the G20 Finance Ministers. Retrieved from https://www.oecd. org/tax/tax-policy/tax-certainty-report-oecd-imf-report-g20finance-ministers-march-2017.pdf

Jacob, M., \& Jacob, M. (2013). Taxation, dividends, and share repurchases: taking evidence global. Journal of Financial and Quantitative Analysis, 48, 1241-1269.

Jacob, M., \& Michaely, R. (2017). Taxation and dividend policy: the muting effect of agency issues and shareholder conflicts. Review of Financial Studies, 30, 3176-3222.

Jacob, M., Müller, M. A., \& Michaely, R. (2017). Consumption taxes and corporate investment (SSRN Working Paper). [s.l]: [s.n].

Julio, B., \& Ikenberry, D. L. (2004). Reappearing dividends. Journal of Applied Corporate Finance, 16, 89-100.
Klassen, K. J., \& Laplante, S. K. (2012). Are U.S. multinational corporations becoming more aggressive income shifters. Journal of Accounting Research, 50, 1245-1285.

Lee, Y.-T., Liu, Y.-J., Roll, R., \& Subrahmanyam, A. (2006). Taxes and dividend clientele: evidence from trading and ownership structure. Journal of Banking and Finance, 30, 229-246.

Markle, K. (2016). A comparison of the tax-motivated income shifting of multinationals in territorial and worldwide countries. Contemporary Accounting Research, 33, 7-43.

McClure, R., Lanis, R., Wells, P., \& Govendir, B. (2018). The impact of dividend imputation on corporate tax avoidance: the case of shareholder value. Journal of Corporate Finance, $48,492-514$.

Oswald, D., \& Young, S. (2004). What role taxes and regulation? A second look at open market share buyback activity in the UK. Journal of Business Finance and Accounting, 31, 257-292.

Patel, E., Seegert, N., and Smith, M. (2017). At a loss: the real and reporting elasticity of corporate taxable income (SSRN Working Paper). [s.l]: [s.n].

Rau, P. R., \& Vermaelen, T. (2002). Regulation, taxes, and share repurchases in the United Kingdom. Journal of Business, 75, 245-282.

Wilde, J. H., \& Wilson, R. J. (in press). Perspectives on corporate tax planning: observations from the past decade. Journal of the American Taxation Association.

Yagan, D. (2015). Capital tax reform and the real economy: the effects of the 2003 dividend tax cut. American Economic Review, 105, 3531-3563. 